Reprod. Nutr. Dévelop., 1988, 28 (2 A), 257-263.

\title{
The use of urea as a marker of body water in the nursing foal
}

\author{
C. GEERKEN (1), M. DOREAU, Sylviane BOULOT
}

with the technical assistance of $H$. DUBROEUCQ $\left(^{*}\right)$ and Renée LEFAIVRE

Laboratoire de la Lactation.

(*) Unité Elevage et Alimentation du Cheval, I.N.R.A., Theix, 63122 Ceyrat, France.

Summary. Urea, compared with deuterium oxide $\left(D_{2} O\right)$ as a reference, was used as a body marker to estimate body water volume in ten 2-month old nursing foals.

Plasma urea clearance was regular over $10 \mathrm{~h}$ and the $\mathrm{R}^{2}$ of the disappearance curve was between 0.93 and 0.98 . Mean urea space was about $4 \%$ lower than $D_{2} \mathrm{O}$ space, but the standard deviation of the proportion of water in body weight was higher with urea $(3.8 \%)$ than with $\mathrm{D}_{2} \mathrm{O}(1.6 \%)$. Calculated urea entry rate was $49 \mathrm{mg} / \mathrm{h} / \mathrm{kg} \mathrm{LW}$.75.

\section{Introduction.}

Dilution techniques for measuring body water are now recognized as the most effective method for the determination of in vivo body composition. At present, the most commonly used markers are those in which the water molecule is labelled with either tritium (radioactive) or deuterium (stable). Urea has been tested as a marker in several species such as dogs (Painter, 1940), cats (Kornberg, Davis and Wood, 1952), man (Bradbury, 1961), sheep (Meissner, 1976), growing cattle (Preston and Kock, 1973 ; Bartle et al., 1987) and cows (Bartle, Males and Preston, 1983). From these studies, the urea dilution space was found to be close to or slightly lower than (98\%) the total body water in dogs and growing cattle, but only $95 \%$ of the deuterium oxide $\left(D_{2} O\right)$ space in man and $90 \%$ of the tritium space in sheep. These differences may be due either to the species or to the method of calculating dilution spaces. Urea space was found to be correlated with the percentage of empty body water and empty body fat in cattle, 12 min after an intravenous injection of a single dose, and was thus proposed for the estimation of body composition (Preston and Kock, 1973). Valuable estimates of body composition have been obtained (Bennett et al., 1982 ; Hammond et al., 1984). Cuba.

(1) Present address : Instituto de Ciencia Animal, Apartado 24, San José de Las Lajas, Habana, 
Isotopic water is now the more usual marker of body water (Robelin, 1973), but the advantage of urea is its low cost and easy analytical determination.

A series of experiments has been performed in France for measuring body composition and milk intake in nursing foals (Doreau et al., 1986 and unpublished data) using $\mathrm{D}_{2} \mathrm{O}$ as a marker. The use of urea as a marker could be an interesting alternative in foals. Foal hay intake being very low, milk is virtually the only component of the diet, and nursing could be considered as a fair approximation of continuous feeding (Doreau and Dussap, 1980). As well as giving estimates of body water and body composition, the use of urea in these conditions should provide valuable information on nitrogen metabolism when the kinetics of the disappearance of the injected dose is analysed.

The present paper compares urea space with the $\mathrm{D}_{2} \mathrm{O}$ space in one of the above experiments and proposes a model for the estimation of urea entry rate and clearance.

\section{Material and methods.}

Ten saddle-breed foals (Anglo-Arab, Selle français), aged 8 to 9 weeks and weighing between 104 and $136 \mathrm{~kg}$, were used. They were milk-fed by the mothers and consumed little hay. Nitrogen intake, calculated from milk intake and composition, was $50.8 \pm 6.5 \mathrm{~g} /$ day.

$\mathrm{D}_{2} \mathrm{O}$ space and milk intake were determined by the technique and model developed for $\mathrm{D}_{2} \mathrm{O}$ kinetics by Doreau and Dussap (1980) taking into account the weight gain of the animals over a 72-hour sampling period. Four days after $\mathrm{D}_{2} \mathrm{O}$ kinetics was studied, the space and kinetics of urea were determined. The foals were $9.0 \pm 0.7$ weeks old and their live weight was $127.6 \pm 9.7 \mathrm{~kg}$.

A dose of $200 \mathrm{mg}$ of urea/ $\mathrm{kg}$ of live weight was injected into the jugular vein in a $0.5 \% \mathrm{NaCl}$ solution containing $25 \%$ urea (Houpt and Houpt, 1971).

Before injection, which began at 10 a.m., three blood samples were taken at 10-min intervals to determine basal plasma urea concentration. Injections were performed through a catheter, after which blood samples were taken at 5, 10, 20, $30,45,60,75,90,120,150,180,240,300$ and 360 min. Heparin was used as an anticoagulant. The urea was determined on plasma with an autoanalyzer and measured by a method using urease (Gutmann and Bergmeyer, 1974).

To calculate urea space and kinetics, the following single compartment model was derived.

$$
E(\mathrm{mg} / \mathrm{min}) \rightarrow\left[\begin{array}{l}
\text { Urea pool } \\
U(\mathrm{~g}) \\
\mathrm{V}(\mathrm{I})
\end{array} \rightarrow \mathrm{S}(\mathrm{mg} / \mathrm{min})\right.
$$

where : $U=$ quantity of urea present at any time, $V=$ urea space ; $E=$ urea entry rate $; S=$ rate of elimination $=\mathbf{f} \times \mathbf{C}=$ flux cleared $\times$ plasma urea concentration. 
When $U$ is increased by a single injection of the dose (D), its rate of decrease is expressed by : $\frac{d U}{d t}=E-S$, where $E$ and $S$ are considered as constants, then $V \frac{d C}{d t}=E-f C$.

After integration and determination of the constants :

$$
\begin{aligned}
C & =\frac{E}{f}+\left(\text { Co }-\frac{E}{f}\right) e^{-\frac{f t}{v}} \\
\ln \left(C-\frac{E}{f}\right) & =\ln \left(\text { Co }-\frac{E}{f}\right)-\frac{f}{V} t
\end{aligned}
$$

where $C_{0}$ is the extrapolated plasma urea concentration at $t=0$, calculated after complete diffusion of the marker. The ratio $E / f$ was considered equal to basal urea concentration (theoretically, the asymptote of equation (1) when $t \rightarrow \infty$; practically, the pre-infusion plasma urea concentration).

The data, taken after equilibration time, were fitted to equation (2) and the equation parameters $\left(C_{0}-E / f\right)$ and $f / V$ calculated. The former term represented the increment of urea concentration caused by the dose, while the latter was the fractional rate of clearance in min.

Urea space was then: $V=\frac{D}{C o-E / f}$

clearance flow : $f=V \times$ fractional rate of clearance and entry rate : $E$ = basal concentration $\times f$.

\section{Results and discussion.}

The injected dose proved to be satisfactory, as no adverse side-effect was observed in the animals, there was no hemolysis in the blood samples, and urea concentrations increased by about $250 \%$ of the basal value.

The plots of In (C - basal value) against time (fig. 1) yielded a straight line after dilution was complete. The disappearance curves showed that the equilibration time in most of the animals was between 5 and $10 \mathrm{~min}$, but reached $20 \mathrm{~min}$ in a few cases. However, a mean equilibration time of $10 \mathrm{~min}$ was obtained by a comparison of the residual standard deviations of the regressions (2), either with all the experimental data or by successive exclusion of the first data: 5, 10, then $20 \mathrm{~min}$. The $R^{2}$ varied between 0.929 and 0.984 for 13 experimental points and were lower than the coefficients found for the disappearance of $\mathrm{D}_{2} \mathrm{O}$, according to the equation of Doreau and Dussap (1980) $\left(R^{2}>0.996\right.$ for 4 experimental points). In cattle receiving labelled urea, Bartle and Preston (1986) obtained $R^{2}$ of 0.98 . The lower accuracy of the urea disappearance curve in our experiment was probably due to the production of urea by the animal. Nevertheless, the adjustment of the experimental points to 


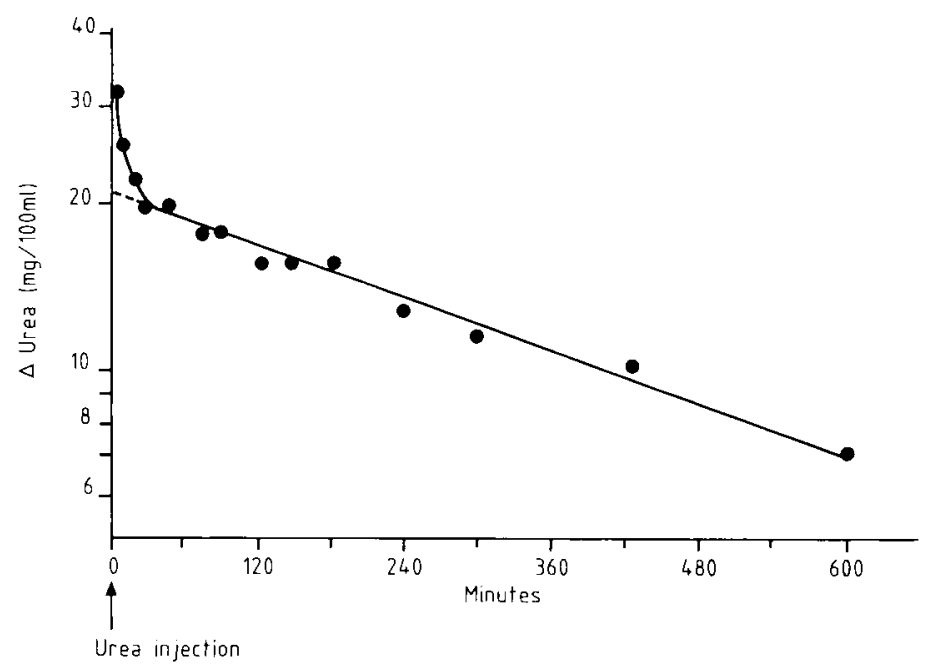

FIG. 1. - An example of urea dissapearence curve in the nursing foal. $\triangle$ urea $=$ concentration - basal concentration.

the linear equation proves the suitability of the monocompartmental model proposed here. Because of the short time required for urea equilibration, no serious loss of the marker would be expected during this time (see Meissner, 1976).

The mean half-life of the injected urea was calculated as $13.6 \pm 4.3 \mathrm{~h}$. Working from the model, we used the linear equation (2) and inserted the mean of the pre-infusion plasma urea concentration value for $E / f$. However, the postequilibration experimental data could be adjusted to the exponential equation (1) by non-linear regression techniques, and $E / f$ obtained as an equation parameter. Nevertheless, it would have been better to extend the sampling period until basal concentration was obtained. With the present data, basal values have been generally overestimated.

Table 1 compares the urea and $D_{2} \mathrm{O}$ spaces. As the urea space was determined several days after the $\mathrm{D}_{2} \mathrm{O}$ space, the latter was estimated as 91.2 liters, i.e. $104 \%$ of the urea space. This result is consistent with data obtained by Bradbury (1961) in man. According to that author, the difference could be the result of two factors: labelling of non-water molecules with hydrogens of isotopic water and failure of urea to diffuse in the central nervous system and cerebro-spinal fluid. A t-paired test showed no difference between urea and $\mathrm{D}_{2} \mathrm{O}$ spaces when the latter were not corrected for the 5.5.-day delay between the two measurements. When this correction is taken into account, the two dilution spaces differ significantly $(P<0.05)$. The estimates of body water/live weight ratio gave the same mean, but the standard deviation was higher with urea determination in a group of foals assumed to be homogeneous. 
TABLE 1

Urea and $\mathrm{D}_{2} \mathrm{O}$ spaces and body water estimations in the nursing foal.

\begin{tabular}{ccccc} 
& \multicolumn{2}{c}{ Space (I) (1) } & \multicolumn{2}{c}{ Body water/liveweight $(\%)(2)$} \\
\cline { 2 - 3 } Animal number & Urea & $\mathrm{D}_{2} \mathrm{O}$ & Urea & $\mathrm{D}_{2} \mathrm{O}$ \\
\hline 1 & 84.1 & 82.9 & 67.3 & 70.0 \\
2 & 90.8 & 86.5 & 70.0 & 70.0 \\
3 & 98.2 & 87.4 & 72.3 & 66.9 \\
4 & 80.5 & 88.3 & 62.8 & 69.9 \\
5 & 81.2 & 88.4 & 62.7 & 69.2 \\
6 & 91.7 & 89.8 & 68.5 & 68.0 \\
7 & 96.1 & 93.3 & 71.7 & 70.0 \\
8 & 93.9 & 95.3 & 68.6 & 68.9 \\
9 & 73.7 & 72.4 & 70.5 & 68.8 \\
10 & 88.4 & 87.7 & 74.4 & 73.0 \\
mean & 87.9 & 87.2 & 68.9 & 69.5 \\
s.d. & 7.8 & 6.2 & 3.8 & 1.6 \\
\hline
\end{tabular}

(1) Urea space was determined 5.5 days after $\mathrm{D}_{2} \mathrm{O}$ space. During this time, the probable increase in water volume was about $4 \mathrm{I}$. 1973).

(2) Calculated as urea space/liveweight or $97 \% \mathrm{D}_{2} \mathrm{O}$ space/liveweight (according to Robelin,

Individual extreme values were 66.9 and 73.0 for $\mathrm{D}_{2} \mathrm{O}$ and 62.7 and 74.4 for urea. The higher standard deviation in measurements obtained with urea, together with the less accurate $R^{2}$, as compared with $D_{2} O$, is due to the fact that urea is a major body metabolite. The relationship between urea space (US) and deuterium oxide space (DOS) was: US $=0.910$ DOS $+8.48(n=10)$. The coefficient of correlation, which was rather low (0.73), rose to 0.97 in 7 foals, probably as a consequence of uncontrollable disturbances in the diffusion of one marker in 3 foals.

The estimation of body water as urea space in nursing foals yielded the same results as those reported by Doreau et al. (1986) for foals of the same live weight, and is consistent with published data on young horse body composition (Schryver et al., 1974). In this experiment, urea entry rate was $48.8 \pm 16.1 \mathrm{mg} / \mathrm{h} / \mathrm{kg} \mathrm{LW} \mathbf{L W}^{0.75}$ and total urea clearance was $4.9 \pm 1.3 \mathrm{ml} / \mathrm{min} / \mathrm{kg} \mathrm{LW} \mathrm{LW}^{0.75}$. No information is found in the literature concerning urea metabolism in foals. Prior et al. (1974) reported a urea entry rate of about $80 \mathrm{mg} / \mathrm{h} / \mathrm{kg} \mathrm{LW} .75$ for ponies with the same $\mathrm{N}$ intake level as the foals of the present experiment. For the latter, however, urea entry rate would be considerably less at the same $\mathrm{N}$ intake, due to more rapid weight gain (up to $1.2 \mathrm{~kg} /$ day) resulting in greater $\mathrm{N}$ deposition. The calculated clearance flow would represent a sum of the amounts cleared by the kidney and possibly by the intestine (Harmeyer and Martens, 1980).

This experiment suggests that urea can be used as a marker for measuring body water in nursing foals despite slight differences between the two markers. In other respects, the use of a model for analysing kinetic data allows a more valid 
estimate of the dilution space than calculation based on only one fixed time after equilibrium. The method can be used in adult horses; however, another more specific study is required because of their higher rate of urea metabolism (Prior et al., 1974), less regular intake of non-protein nitrogen, and their utilization of urea in the large intestine.

Reçu en septembre 1986.

Accepté en octobre 1987.

Acknowledgements. - Sincere thanks are due to J. Robelin for his valuable comments on this paper.

Résumé. Utilisation de l'urée comme marqueur de l'eau corporelle chez le poulain allaité. On a injecté à 10 poulains allaités âgés de 2 mois de l'urée, marqueur de l'eau corporelle, afin d'estimer leur volume d'eau corporelle. L'urée a été comparée avec l'eau lourde, marqueur de référence.

La disparition de l'urée du plasma a été régulière sur une durée de 10 heures. Le coefficient de détermination de sa courbe de décroissance en fonction du temps a été compris entre 0,93 et 0,98. L'espace de diffusion de l'urée a été en moyenne de $4 \%$ inférieur à celui de l'eau lourde. L'écart-type du pourcentage de l'eau corporelle dans le poids vif a été plus élevé avec l'urée $(3,8 \%)$ qu'avec l'eau lourde $(1,6 \%)$. Le taux d'entrée de l'urée dans l'organisme a été de $49 \mathrm{mg} / \mathrm{h} / \mathrm{kg}$ de poids métabolique.

\section{Références}

BARTLE S. J., MALES J. R., PRESTON R. L., 1983. Evaluation of urea dilution as an estimation of body composition in mature cows. J. anim. Sci., 56, 410-417.

BARTLE S. J., PRESTON R. L., 1986. Plasma, rumen and urine pools in urea dilution determination of body composition in cattle. J. anim. Sci., 63, 77-82.

BARTLE S. J., KOCK S. W., PRESTON R. L., WHEELER T. L., DAVIS G. W., 1987. Validation of urea dilution to estimate in vivo body composition in cattle. J. anim. Sci., 64, 1024-1030.

BENNETT G. L., SWIGER L. A., PRESTON R. L., CAHILL V. R., 1982. Evaluation of urea space and ultrasonic measurement as selection criteria for beef animal composition. J. anim. Sci., 54, 553-558.

BRADBURY M. W. B., 1961. Urea and deuterium oxide spaces in man. Br. J. Nutr., 15, 177-182.

DOREAU M., DUSSAP G., 1980. Estimation de la production laitière de la jument allaitante par marquage de l'eau corporelle du poulain. Reprod. Nutr. Dévelop., 20, 1883-1892.

DOREAU M., BOULOT S., MARTIN-ROSSET W., ROBELIN J., 1986. Relationship between nutrient intake, growth and body composition of the nursing foal. Reprod. Nutr. Dévelop., 26, 683690.

GUTMANN I., BERGMEYER H. U., 1974. Urea. In BERGMEYER H. U., Methods of enzymatic analysis, vol. 4, 1791-1801, Verlag Chemie Weiheim, Acad. Press.

HAMMOND A. C., RUMSEY T. S., HAALAND G. L., VARGA G. A., 1984. Comparison of urea space estimation of empty body fat to direct chemical measurement of empty body fat in steers. J. anim. Sci, 59, supp. 1, 213 (abstract).

HARMEYER J., MARTENS H., 1980. Aspects of urea metabolism in ruminants with reference to the goat. J. Dairy Sci., 63, 1707-1728.

HOUPT T. R., HOUPT K. A., 1971. Nitrogen conservation by ponies fed a low-protein ration. Am. J. vet. Res., 32, 579-588. 
KORNBERG H. L., DAVIS R. E., WOOD D. R., 1952. Measurement of total body-water with urea. Nature, 169, 502-503.

MEISSNER H. M., 1976. Urea space versus tritiated water space as an in vivo predictor of body water and body fat. S. Afr. J. agric. Sci, 6, 171-178.

PAINTER E., 1940. Total body water in the dog. Am. J. Physiol., 129, 744-755.

PRESTON R. L., KOCK S. W., 1973. In vivo prediction of body composition in cattle from urea space measurements. Proc. Soc. exp. Biol. Med., 143, 1057-1061.

PRIOR R. L., HINTZ H. F., LOWE J. E., VISEK W. J., 1974. Urea recycling and metabolism of ponies. J. anim. Sci., 38, 565-571.

ROBELIN J., 1973. Estimation de la composition corporelle des animaux à partir des espaces de diffusion de l'eau marquée. Ann. Biol. anim. Bioch. Biophys., 13, 285-305.

SCHRYVER H. F., HINTZ H. F., LOWE J. E., HINTZ R. L., HARPER R. B., REID J. T., 1974. Mineral composition of the whole body, liver and bone of young horses. J. Nutr., 104, 126-132. 